\title{
Deviant Behaviors of Teenage Drug Users
}

\author{
Warsono \\ Faculty of Social Sciences and Law \\ Universitas Negeri Surabaya \\ Jalan Ketintang, Surabaya 60231, Indonesia \\ warsono@unesa.ac.id
}

\author{
Sarmini \\ Faculty of Social Sciences and Law \\ Universitas Negeri Surabaya \\ Jalan Ketintang, Surabaya 60231, Indonesia \\ sarmini@unesa.ac.id
}

\section{Syarifah Hasanah \\ Social Studies}

Universitas Negeri Surabaya

Jalan Ketintang, Surabaya 60231, Indonesia

Syarifahhasanah80@gmail.com

\begin{abstract}
Drugs seems to be an endless problem and become an international problem which can be a serious threat to our next generation. This paper focused on the problem of drug abuse among teenagers in a region in East Java. The setting of this research was state vocational senior high school because the number of drug users was higher than students from other educational institutions. This research used qualitative research method with case study approach and the sampling method used was purposive sampling. Data were collected using interviews and in-depth interviews, participant observation, documentation or recording of archives. Data were analyzed using Miles and Huberman (1994) analysis with data reduction technique, data presentation, conclusion and verification. The results of this research concluded that the other deviant behaviors performed by the students are: 1) primary negative deviations was illegal street racing, 2) the secondary deviations were ditching, leaving lessons at certain hours, not paying attention to lessons or sleeping during lessons, often neglecting school duties or obligations, arguing or disputing, lying, selling and stuffing his belongings without telling thier parents, picking things without the owner's permission (stealing), free sex, and sexual deviation (lesbian or gay).
\end{abstract}

\section{Keywords- Drug users, deviant behavior forms, teenagers}

\section{INTRODUCTION}

Many countries in the world facing an urgent problem, the problem of drugs is increasingly threatening. Currently Indonesia has declared drug emergency because drugs have entered into various layers of society including teenagers Drug use by adolescents is one form of deviant behavior that is very dangerous because the impact is very dangerous especially for the user's body, and adolescents are a group that is easily affected drug abuse. One reason teens are very easy to be victims of drug abuse is because they are in the process of searching identity and tend to have an unstable soul.

Based on the survey results of the National Narcotics Agency [1] retrieved data is that the average age of first abuse of drugs at a very young age that is $12-15$ years. The number of narcotics abuse among students to ever wear of 7.5 percent and the share of 4.7 percent a year. The higher the age group, so the higher the number of the drug abuse. And the higher the level of education, the greater the number of drug users [2], [3].

East Java is one of the provinces in Indonesia with high drug abuse rate amount. The bustling drug cases in East Java pushed the number of research about drugs in this island of which namely research on Lumajang [4], Kediri [5], Malang [6], Batu [7], Mojokerto [8], and Jember $[9 ; 10]$. Their Reseach shows the fact that the problem of drugs in East Java like an iceberg, which drug abuse looks a little but actually more than that.

Currently every district in East Java is inseparable from drug problems and the location of this study is one of the districts with a fairly unsettling drug distribution that began to touch teenagers [11]. This area of research is a well known religious area and predominantly Muslim, but drug cases are rife here. This fact is inversely proportional, where should the majority Muslim community can reject the entry of drugs that are prohibited by religion but even more in demand by the local population. Based on data from the Narcotics Agency (BNK), the drug distribution in its territory is already severe, and it touches all levels of society, including the village head. Approximately 50 percent of village heads spread across 14 districts in the region have involved drug cases. Circulation of drugs in this Regency also began to touch the child's age, proved by the existence of drug users who are still under age. The distribution network of drugs in this region is mostly supplied from Malaysia [12]. This regency is even the 
second highest in East Java as a place of drug trafficking. The following drugs case data was obtained from units of drug resorts in a region in east java from January 2015 to 2016.

TABLE I. Drug CASES On UNITS OF Drug RESORTS PERIOD 2015-2016

\begin{tabular}{|c|c|c|c|c|}
\hline \multirow[b]{2}{*}{ NO } & \multicolumn{4}{|c|}{$\begin{array}{l}\text { DRUG CASES ON UNITS OF DRUG RESORTS } \\
\text { PERIOD 2015-2016 }\end{array}$} \\
\hline & \multicolumn{2}{|c|}{ Category } & $\begin{array}{c}\text { The } \\
\text { Number } \\
\text { Of } \\
\text { Drug } \\
\text { Cases } \\
\text { in } 2015\end{array}$ & $\begin{array}{c}\text { The } \\
\text { Number } \\
\text { Of Drug } \\
\text { Cases in } \\
\text { January- } \\
\text { May } \\
2016\end{array}$ \\
\hline \multirow[t]{3}{*}{1} & \multirow[t]{3}{*}{ AGE } & $<18$ & 3 & 3 \\
\hline & & $>19-25$ & 23 & 23 \\
\hline & & $>26-45$ & 44 & 28 \\
\hline \multirow[t]{5}{*}{2} & \multirow[t]{5}{*}{ EDUCATION } & $\begin{array}{l}\text { ELEMENTARY } \\
\text { SCHOOL }\end{array}$ & 25 & 27 \\
\hline & & $\begin{array}{l}\text { YUNIOR HIGH } \\
\text { SCHOOL }\end{array}$ & 16 & 9 \\
\hline & & $\begin{array}{l}\text { SENIOR HIGH } \\
\text { SCHOOL }\end{array}$ & 23 & 16 \\
\hline & & UNIVERSITY & 5 & - \\
\hline & & $\mathrm{NON}$ & 1 & 2 \\
\hline \multirow[t]{6}{*}{3} & \multirow[t]{6}{*}{ OCCUPATION } & PRIVATE & 44 & 38 \\
\hline & & $\begin{array}{l}\text { SELF } \\
\text { EMPLOYED }\end{array}$ & 14 & 4 \\
\hline & & STUDENT & 1 & 1 \\
\hline & & $\begin{array}{l}\text { COLLEGE } \\
\text { STUDENT }\end{array}$ & - & 1 \\
\hline & & $\begin{array}{l}\text { CIVIL } \\
\text { SERVANT }\end{array}$ & 2 & 2 \\
\hline & & UNEMPLOYMENT & 7 & 8 \\
\hline \multirow[t]{2}{*}{4} & \multirow{2}{*}{$\begin{array}{c}\text { THE STATUS } \\
\text { OF A } \\
\text { SUSPECT }\end{array}$} & HUSTLER & 18 & 40 \\
\hline & & USERS & 52 & 14 \\
\hline
\end{tabular}

${ }^{\text {a. }}$ Sample of a Table footnote. (Table footnote)

Based on Fig.1 above, understand that the number of cases happened in this region increased from the year 2015 as 278 cases become 216 cases in the middle of 2016 and in them are students being users of drugs

Research on drug abuse has been widely practiced by researchers, including research on the effects of drug use conducted by Rahman, Adiyalmon, \& Prahara [13], that the impact of adolescent behavior by using drugs is (1) disturbing public order (stealing, squabbling), ( 2) damaging the next generation, and (3) disturbing public order like wild racing around the mosque and doing nightclubs at night. Similar to previous research, Anggreni [14] said that the impact of drug use makes one become more daring or careless, pretentious, lying, cheating, picking, selling someone else's stealth and even stealing. Vehbiu \& Bodinaku said that the worst effects of narcotic use can lead to users committing suicide [15].

\section{RESEARCH METHODS}

This research uses qualitative research method, is research that can show people's life, history, behavior, technique 's organization, social movement and kinship [16]. The approach of this research is case study, that is intensive, detailed and deep approach to a certain organization, institution or symptom [17]. This study also used an intrinsic case study because researchers wanted to know in depth, intensive and detailed cases of drug abuse by students - especially how teenage drug users behavior and how the results of research from drug users. The technique of selecting informants in this study is called purposive sampling technique in which the researcher tends to choose informants who meet certain criteria and are considered trustworthy and know the accurate data source and know the existence of the problem [18]. Researchers selected as key informants should be the criteria: Students of vocational school in region in east java who use drugs. Data collection techniques in this study are in-depth interviews, interviews, participatory observation and documentation or archives. Qualitative data analysis consists of three activities, including: (1) data reduction, (2) data presentation, (3) drawing conclusions and verification [19].

\section{RESULTS AND DISCUSSION}

This research report writing, the names of informants were intentionally not written complete only with the initials YF, AM, TN, DK and SLM. Following the results and a discussion of the behavior deviant conducted by students of vocational school in this region taking drugs.

A. Forms of deviant behaviour committed by students of vocational school in region in east java who use drugs

1. The Primary Deviation is a wild race

Primary deviation also referred to light aberrations. The perpetrators of these aberrations are generally not aware that he was doing the irregularities. Primary deviation do not continuously (incidental) and generally not so detrimental to others. Based on the results of observation and interview, students who use drugs do primary aberration in the form of a wild race. The usual wild races conducted by informants on the street in this region, known as Bong Later (new road). The following utterance YF:

"... have challenged with the students of senior high school mom. Because TN often troubled with the students of that school. At Saturday night we received the challenge. previously we used to let gathered and sucked drugs/methamphetamine to have the energy and courage more."(YF, 2017)

The Utterance's YF justified by TN as follows:

“...students of senior high school hostile challenged me mom, to show the power in shootout races. me and my gang is ready to accept the challenge."(TN, 2017).

Based on the known informant interviews that before doing a wild race, they put sabu with the aim to boost their 
courage and strength. YF, AM, TN and DK at that time experiencing a victory against a gang kid of senior high school (MAN). They believe that their victory because they wore previously methamphetamine before the race.

Based on the results of the interviews, researchers concluded that the primary form of deviant behavior of the races of the wild are affected by drug usage. Methamphetamine is here used as one of the ways that they may have the strength and courage to win the race. Although the use of intentional here to get methamphetamine did a wild race of deviant behavior, but they also have experience of how Methamphetamine could make them feel pleasure and not fear any danger. The following utterance AM:

"...after using methamphetamine, we automatically want to bring the vehicle with high speed and dare to challenge the race with pleasure. (YF, 2017)

Based on the above interviews, AM added that at the time of using methamphetamine, can make them want to drive vehicles at high speed. though No one challenged them for the race, but wearing a methamphetamine can make them spur their vehicle unreasonably.

Differential association theory proposed by E. Sutherland [20] mentions that the deviation occurs because the deviation has been learned by a person or group of people. Racing wild when using drugs or while using drugs conducted by YF, AM, DK and TN done because they have witnessed that some wild racers wearing methamphetamine when doing wild races. They see that wearing a methamphetamine can help their action win the race. This deviant behavior is also in accordance with social bond theory by Travis Hirschi [21]. This theory says that deviation is the result of a vacuum of control or social control. This theory is built on the view that every human being tends to disobey the law or has the impetus to commit a lawlessness. Deviant behavior is a logical consequence of a person's failure to obey the law.

This study is also in accordance with research conducted by Rahman et al [ 13] who found that the impact of drug use among others is disturbing public order such as speeding up around the mosque at night. Research conducted by Anggreni [14] also found that drug use makes one become more daring or reckless. Evidently through these informants, while still in the influence of drugs, they will not feel fear and more daring and desperate to race wildly though with the risk will be arrested by the officers.

\section{The Secondary Deviation}

For the teenage drug users, a secondary deviation is the deviation of the most frequently encountered and performed by them. Departures performed a real person and always going on, so that it can be quite severe and disturbing other people. Using drugs including one form of deviant behavior and tend to give birth to other deviant behavior. The following secondary Deviation of the most widely performed by the student drug users in this region are likely following items:

a) Ditching

Ditching is the usual form of the offence committed by the fifth of these children, by the YF, AM, TN, DK and SLMN. Although not every day, but often the intensity when compared with other friends who were classmates with them. DK spoke as follows:

"...I often stay up late, so can not get up in the morning. Instead of being late and told to go before counseling guidance (BP), it's better not to go all the way. Ya Ma'am, we still feel flying. Maybe if I do not smoke methamphetamine then I can get up and not ditching. " (DK, may 8 2017)

Similar with YF, AM also said as follows:

"... more ditching because all night not sleep. The morning time the effect of methamphetamine is already diminished, and my eyes could not be opened. (PM, may 8, 2017)

The utterance YF and AM informed that since often do drugs, ditching their intensity more often. Stay up without do drugs alone has made the sleepy e.g. day, let alone staying out while wearing shabu. Effect of nge-fly because methamphetamine in the morning still exist and make them reluctant to attend school. In Sutherland's ninth proposition, it is said that the process of studying deviant behavior through groups or associations is also distorted or otherwise. Behavior ditch by YF, AM, DK and TN they do because they are still a gang that often spend time together.

\section{b) Leaving class at the lessons}

If ditching it has often been performed by five children, as well as other infractions like leaving a lesson at certain hours. Both YF, AM, DK., TN and SLM ever and even often leave the lesson at certain hours. The following utterance bySLM:

". .. depends, almost all the lessons I ever leave. usually in our cafeteria back near the fence that collapsed. I did it twice and just carry LL and koteng. (YF, may 8, 2017)

Based on the results of interviews with informants, note that drug use by the five informant this affects their activity in the classroom. The fifth this informant felt lazy and did not feel excited in the classroom so they out out of the class and leave the lesson. The time they spend for staying up and suck the methamphetamine to make the next morning when the school became excited. and they are feel agonizing in the class.

Based on a third sutherland proposition [20], that deviation occurs as a result of intimate association, while mass media (TV, magazine and newspaper) play only a secondary role. YF, AM, TN and SLM have close intimacy with each other because they are friends of one gang. They can not invite friends outside their gang because it is feared that they will endanger them 
Based on social control theory Travis Hirschi [21], the deviant behavior occurs because there is no control or the existence of a vacuum of control from the school that carelessly supervise their students so that the school space is strategically used for hanging out. Incidentally because the school fence on the back has begun to collapse, it is very easy for these students to serve as a door to sneak out of school without having to pass the security guard in front.

c) Does not pay attention to the lesson/sleeping at the time of the lesson

Other secondary deviation is often done by YF, a.m., D.K., TN and SLM due to drug use that is not paying attention to the lesson/sleeping at the time of lessons AM also said secondary deviation is doing when finished used the AM:

" When at night party with Methamphetamine, then tomorrow morning or afternoon would be sleepy. and I do not think smart and lazy. " (AM, may 8, 2017)

Based on the results of interviews and observations conducted by the researcher then it can be inferred that all four of them have a habit of staying up somehow with his friend one gang or with neighbors about their hometown. Just stayed up late at night will make them sleepy in the morning. Especially if they are done do drugs, a sense of perceived growing sleepy.

If it is associated with social control theory [21], sleeping behavior during lesson hours is slightly inconsistent with this theory because there is no vacuum of control by teachers that cause sleep-free pupils. Each teacher has its own way so that the students do not fall asleep in the classroom as do the teachers of Civics and mathematics. However, when viewed from the fifth side of this informant, then sleep when the lesson takes place is an inability of the informant to control himself and control his drowsiness as a result of their frequent stay up for methamphetamine, drunk or just to drink coffee and smoking alone resulting in drowsiness in the morning day. the results of this study are relevant to the results of studies conducted by heffernana et al [22] that adolescents who use excessive amounts of alcohol or drugs have a selective deficit in their ability to engage in daily activities that depend on memory.

d) Often neglect the duties or obligations of the school

The duty of a student is the most important is learning. This obligation is often considered to be a forced to and prison for PM, DK, YF and TN. Despite this, the SLM including students who still put the interest and desire of learning not as a third friend. The task is a form of assessment that was given by the teacher to find out the students capable to absorb the lessons and the knowledge they have gained. All five of these students feel the task is a a forced to they need to do and accomplish. This makes the fifth drug informants often ignore other school tasks and the other duty, as spoken by YF follows:

"... How'd like working on mom, already difficult concentration plus often ditching. make $\mathrm{i}$ Was not connected what tasks need to be done. I also often use the tuition to buy cigarettes, drink and suck the methamphetamine.... " (YF, may 8, 2017).

Juvenile delinquency such as neglecting school duties and obligations is in accordance with the ninth proposition [20] which states that this deviant behavior including delinquency is considered a common value. TN and his friends assume it is usual not to do the duties and obligations because it will eventually be passed as long as it is not found out to commit grave violations.

\section{e) Fighting}

The next deviant behavior performed by the students of these drug users is disagreement with others. Each student either AM, YF, DK, TN and SLM has a different story. The first YF informant confessed to commit deviant behavior such as a fight with classmates and friends outside of school, sometimes because of trivial issues such as mutual taunted and joked that outrageous. as YF says as follows:

"...I do not like the most laughing at my emotions easily, if anything is a bit embarrassing. I am also against teachers because she speaks poorly about me in front of my friends and teachers of other teachers. "(YF, may 8, 2017)

YF's words informed him that he was an emotionally vulnerable person because of problems of mutual reproach or anyone who dared to evil and step on his self-esteem. YF also does not care even though the teacher is opposed. If the methamphetamine effect still exists, then the fear is never felt and the desire to fight or challenge anyone who dares to provoke emotion.

DK quarreled with his classmate in accordance with Sutherland's theory, that DK hit back when his friend repeatedly joked outrageously. This study is also in accordance with related research conducted by Rahman et all [13], that the impact of adolescent behavior using drugs is disturbing public order such as quarreling and stealing.

f) Lie

Many of the goals desired by the students so as to lie fifth was chosen as the way to launch. YF earn pocket money amounting to ten thousand dollars per day from umi/grandmother. This money is not enough to satisfy his diverse like to buy cigarettes, buy methamphetamine, streets or other wishes. The following utterance YF:

"... lie is the only way to earn money. I usually ask for money from my grandmother. The most frequent reason was donation to task, for printed the tasks, and for photocopy."(YF, may 8, 2017)

Based on interviews with the five informant, known that drug users have a tendency to lie to cover up his behavior or lied to launch action do drugs. If based on observation, TN including one of the informants who have behavior to lie more often than with his friends in the other. According to differential association theory, lying is a behavior they learn from their friends to facilitate their 
goals, especially to consume methamphetamine. This behavior also conforms to Hirschi's social control theory [21] that the behavior lies due to a vacuum of control. Like the DK, where his mother always believe and will always provide all his needs, especially if the reasons for the school.

\section{g) Selling household goods}

Other alternatives so that the desire to suck methamphetamine are met can be obtained by selling the mortgaged goods and without the know of the parents. Engineering Computer Network requires their students at least have your own computer or laptop. Most of these students have it in order to facilitate and streamline the learning process. Among the five children, only AM alone which does not have its full due must be used both with his twin brother. The laptop is an object which is often pawn by these students especially when they have absolutely no money to buy methamphetamine as spoken by YF follows:

" we ran out of money while apprenticing in Malang and we wanted to buy a heaven drink (methamphetamine), but we do not have the money. At that time we also ran out of money for the cost to going home because there are three days off. Finally I pawned my laptop for six hundred thousands." (YF, may 8, 2017).

Based on their experience, the safest way to earn money is to sell and mortgage the goods they have. This behavior is learned from the people closest to them who often sell or mortgage their valuables if forced for immediate needs. Their behavior is in accordance with Sutherland's theory of learning from the people closest to him.

h) take the goods without permission from the owner (stealing)

Take things without permission of its owner is a form of deviant behavior committed by drug users. Only TN ever caught stealing and taking his friend's money. If only dare to take YF money in his shop is no more than 50 thousand and permitted by the grandmother, DK also often take money in the wallet at birth. In contrast to $\mathrm{TN}$, what happened when he was an apprentice in Malang. The following utterance: YF:

"the beginning of the fight I was facing with TN because he took the money to pawn the results of my laptop. Since we're not close anymore, for me he's a betrayal." (YF, May 13, 2017)

Based on the results of interviews with the five informants, some of them never took possession of another person without permission to get drugs. TN included one informant who caught taking money belongs. This behavior is in accordance with Hirschi's social control theory [21] that deviant behavior occurs because of a control vacuum, a DK behavior that easily takes his parents' money without permission and the absence of sanctions or penalties from his parents is evidence of no parental control to reduce the DK's behavior. This aberrant behavior such as stealing is also in accordance with research conducted by Anggreni [14]

\section{i) Free Sex}

Free sex is often done by drug users, but in this study only one person who did it. TN is one of the informants who have higher drug addiction rates when compared with his friends. TN is famous for having many girlfriends. following the TN statement:

".... I have a lot of girlfriends, there are junior high school and high school too .. The important thing is pretty, nice and willing with me, feels there is less when dating not play sex, while sucking meth must be more exciting." (TN, May 16, 2017)"

Based on TN statement indicates that the force of courtship of the TN has been over-passed the norm line. Free sex for him is normal and he considers dating without sex is something boring. Using Methamphetamine makes TN seem always addicted, not only addicted to methamphetamine but also freesex addiction.

Based on interviews with this informant, the fifth note that TN is the only source that is not only addicted to drugs but also free sex addiction and the two often do together. Due to free sex with his girlfriend, now TN already have children. If it is associated with Hirschi's social control theory [21], then this behavior is also appropriate that free sex is a form of TN's inability to control its behavior. TN does not realize that his behavior is one of the big sins that is prohibited by religion and will bring some impact in his life.

\section{j) LGBT}

Sexual behavior with same-sex known as LGBT is one of deviant behavior is also often done by drug users. The sex deviation in this case is only done by SLM. SLM is known as a quiet, obedient and diligent student who has committed sexual and harmful deviations from his other friends, as revealed by the following SLM:

$$
\begin{aligned}
& \text { "... I'm stuck mom, I do not think going into their } \\
& \text { world SNL has tricked me Maybe Mr. FTH has told } \\
& \text { everything to you mom." (May 14, 2017) }
\end{aligned}
$$

SLM is a quiet boy who is not easy to reveal the secrets of his life except only to people he trusted. SLM only trust in Mr. FTH. SLM says that he has been framed by his close friend. SLM is sold to a transvestite by his friend. In drinks and cigarettes provided by transvestites on SLM has been put in drugs in it. After several attempts, SLM was able to enjoy methamphetamine, then after that little by little SLM began to be invited to serve sex by the transvestites. SLM initially felt annoyed for being cheated by his friend, but needs to beat everything. All the needs of SLM fulfilled since he became the satisfaction of the passion of the transvestites. SLM is easy to get drugs, money and can fulfill all the needs of his life from the transvestites. 
According to different association theories [20], SLM behavior can be reviewed in detail through several propositions put forward by Sutherland following: a) The same sex deviation is negatively studied from peers and is not inherited. SLM serves the sex of transvestites since the first grade of vocational school because it is learned from a close friend who has trapped him into this behavior, b) SLM deviant behavior learned through the process of interaction with close friends in the village that every day after school when the SLM is always spent with them.Delinquency SLM studied with participation with a close friend who has introduced it in the world of transvestites, c) The process of studying behavior usually occurs in a very intimate group of friends. SLM knows the ins and outs of the world of transvestites from his little friend who is also his neighborhood. d) If juvenile delinquency can be studied, the lessons learned include: i) a very difficult technique of doing evil sometimes very easy, ii) the specific direction of motives, impulses, rationalizations, attitudes.

\section{CONCLUSIONS}

Based on the results of research that has been done can be drawn the conclusion that: The form of deviant behavior of drug users conducted by students in vocational schools in region in east java, the first is the deviation of primary behaviors such as wild racing where the use of methamphetamine can make these students brave and they believe that methamphetamine can help they won the wild race. This behavior they learned from friends who have often used methamphetamine when the race and this is in accordance with the theory of different associations proposed by E.Sutherland. The second form of deviation is secondary deviation, which is often done by five teenagers that include ditching, out of class when lessons, sleeping during lessons, often ignore school duties / obligations, fighting, lying, and selling or mortgaging goods without permission, take the goods without permission from the owner (stealing), free sex and the last one is LGBT. all these secondary deviations become a behavior they often do as a result of drug use. This behavior proves the existence of a vacuum of control as proposed by Travis Hirschy.

\section{Acknowledgment}

Thanks to P2TK Kemendikbud who has given scholarships to me so I can further study majoring.

\section{References}

[1] BNN. (2009). Ringkasan Journal Data P4GN 2009 Edisi 2010.pdf. obtained from www.bnn.go.id/portal/_uploads/.../Jurnal_Data_P4GN 2009_Edisi_2010_Oke.pdf.

[2] BNN. (2013). Ringkasan Journal Data P4GN 2013 Edisi 2014.pdf. obtained www.bnn.go.id/portal/_ uploads/.../Jurnal Data P4GN 2013_Edisi_2014_Oke.pdf.

[3] BNN. (2016). Laporan kinerja BNN tahun 2015 - 2016 obtained from www.bnn.go.id/_multimedia/.../laporan_kinerja_bnn_2 015-20160311155058.pdf.

[4] Pratama, V.N.D. (2013). Perilaku Remaja Pengguna Minuman Keras di Desa Jatigono Kecamatan Kunir Kabupaten Lumajang. Jurnal Promkes, Vol.1(2), 145 152.

[5] Wury, F.H. (2013). Perilaku Menyimpang Remaja: Studi Kasus Penyalahgunaan Narkoba di Kabupaten Kediri. (Tesis Master). Universitas Negeri Surabaya, PPIPS.

[6] Zhafarina, A.N., Endrawati, L., \& Istiqomah, M. (2014). Penanganan Polri untuk Pelaku Peredaran Narkotika oleh Pekerja Informal di Kota Malang. Skripsi. Fakultas Hukum Universitas Brawijaya.

[7] Hutabarat, R.LF. Faktor-faktor Penyebab Kenakalan Remaja (Studi Kasus Pengguna Narkoba di Desa Perumnas Simolingkar Kecamatan Pancur Batu.

[8] Widyawati, W. (2015). Persepsi Remaja tentang Penyalahgunaan Narkoba di SMK Kusuma Bangsa Bangsal Kabupaten Mojokerto.

[9] Wulandari, C.M., Retnowati, D.A., Handojo, K.J., \& Rosida. (2015). Faktor-faktor yang Mempengaruhi Penylahgunaan NAPZA pada Masyarakat di Kabupaten Jember. Jurnal Farmasi Komunitas, Vol. 2(1), 1 - 4.

[10] Saleh, H.D., Rokhmah, D., Nafikadini, I. Fenomena Penyalahgunaan NAPZA di Kalangan Remaja ditinjau dari Teori Interaksionisme Simbolik di Kabupaten Jember. E-jurnal Pustaka Kesehatan, Vol. 2(3).

[11] Madura Expose (2015, Februari 20). "Gawat Kabupaten Sampang masuk catatan merah BNN", diperoleh dari www. Madura expose.com/gawatkabupaten-sampang-masuk-catatan-merah-bnn.

[12] SuaraSurabaya (2015, Oktober 15). "BNN Polda Jatim tangkap bandar narkoba di Sampang", diperoleh dari Kelanakota.SuaraSurabaya.net/news/2015/160799-

BNN-Polda- Jatim-Tangkap_Bndar-Narkoba-diSampang.

[13] Rahman, Z. Y. A., Adiyalmon, Prahara, S. (2014). Dampak Perilaku Remaja Pengguna Narkoba di Nagari Lubuk Gadang Kecamatan Sangir Kabupaten Solok Selatan. Artikel" STKIP PGRI Sumatera Barat Padang.

[14] Anggreni, D. (2015). Dampak Bagi Pengguna Narkotika, Psikotropika dan Zat Adiktif (NAPZA) di Kelurahan Gunung Kelua Samarinda Ulu. E-jurnal Sosiatri-Sosiologi, Vol.3(3), 37- 51.

[15] Vehbiu, B., \& Bodinaku, B. (2014). Prevalence of Suicidal Behavior Among Male Drug Users in Kosovo. Social and Behavioral Sciences, 159, 375 - 380.

[16] Ghony, D. dan Almanshur. F. 2014. Metodologi Penelitian Kualitatif. Ar-Ruzz Media: Yogyakarta).

[17] Arikunto, S. (1997). Prosedur Penelitian Suatu Pendekatan Praktek. Jakarta: Penerbit Salemba Humanika. 
[18] Nasution, Metode Research: Penelitian Ilmiah. Jakarta: Bumi Aksara, 2007.

[19] Miles, MB dan Huberman, AM., 1994. Qualitative Data Analysis. 2nd penyunt. London: Sage Publications Ltd.

[20] Siahaan, M.S. J. (2009). Perilaku Menyimpang Pendekatan Sosiologi. Jakarta: PT Indeks.

[21] Narwoko, S.J., \& Suyanto, B. (2004). Sosiologi Teks Pengantar dan Terapan. Jakarta: Kencana Media Group.

[22] Heffernana.T., et all (2006). Does excessive alcohol use in teenagers affect their everyday prospective memory?. Clinical Effectiveness in Nursing. Vol.9(3), p. e302-e307 